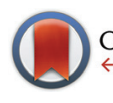

CrossMark \&lick for updates

Cite this: Dalton Trans., 2016, 45 4570

Received 27th November 2015, Accepted 28th January 2016

DOI: $10.1039 / c 5 d t 04656 d$

www.rsc.org/dalton

\title{
Transfer hydrogenation with abnormal dicarbene rhodium(III) complexes containing ancillary and modular poly-pyridine ligands $\uparrow$
}

\author{
Kevin Farrell, ${ }^{a}$ Philipp Melle, ${ }^{a}$ Robert A. Gossage, ${ }^{b, c}$ Helge Müller-Bunz ${ }^{a}$ and \\ Martin Albrecht*a,b
}

\begin{abstract}
Treatment of an abnormal dicarbene ligated rhodium(III) dimer with 2,2'-bipyridine (bipy), 1,10-phenanthroline (phen) or 2,2':6',2'-terpyridine (terpy) results in coordination of the $\mathrm{N}$-donor ligands and concomitant cleavage of the dimeric structure. Depending on the denticity of the pyridyl ligand, this situation retains one $(\mathrm{L}=$ terpy) or two $(\mathrm{L}=$ bipy, phen) flexible sites for substrate coordination. In the case of the bipy complexes, modification of the electron density at Rh, without directly affecting the steric environment about the metal centre, was achieved by the incorporation of electron-donating or electron-withdrawing substituents on the bipy backbone. The dicarbene pyridyl complexes were active in transfer hydrogenation catalysis of benzophenone at $0.15 \mathrm{~mol} \%$ catalyst loading in a $\mathrm{PrOH} / \mathrm{KOH}$ mixture. The catalysts displayed a strong characteristic colour change (yellow to purple) after activation which allowed for visual monitoring of the status of the reaction. The colour probe and the robustness of the active catalysts proved useful for catalyst recycling. The catalytic activity sustained over five consecutive substrate batch additions and gave a maximum overall turnover number of 3100 .
\end{abstract}

\section{Introduction}

Poly-pyridines and in particular $2,2^{\prime}$-bipyridine (bipy) and $2,2^{\prime}, 6^{\prime}, 2^{\prime \prime}$-terpyridine (terpy) have been extensively explored as ligands for transition metals, metalloids and main group elements due to the attractive features they impart onto the coordinated centre. ${ }^{1}$ As ligands, they have numerous applications in catalysis, ${ }^{2}$ such as $\mathrm{C}-\mathrm{H}$ borylations, ${ }^{3}$ alcohol ${ }^{4}$ and/or water oxidation, ${ }^{5}$ the aldehyde-water shift reaction, ${ }^{6}$ and simple hydrogenation chemistry. ${ }^{7}$ The pyridyl groups can be electronically modified by incorporation of electron-donating (EDGs) or electron-withdrawing substituents (EWGs) at, for example, the $4,4^{\prime}$-position of bipy. Such substitution offers an approach to tune the properties of the metal centre and thus a flexible handle on catalyst optimisation. With the ongoing development of poly-pyridines and their relatives as privileged ligands

\footnotetext{
${ }^{a}$ School of Chemistry, University College Dublin, Belfield, Dublin 4, Ireland ${ }^{b}$ Departement für Chemie und Biochemie, Universität Bern, Freiestrasse 3, CH-3012 Bern, Switzerland. E-mail: martin.albrecht@dcb.unibe.ch; Tel: +41316314644 ${ }^{c}$ Department of Chemistry \& Biology, Ryerson University, 350 Victoria St., Toronto, ON M5B 2K3 Canada

$\dagger$ Electronic supplementary information (ESI) available: Details on variable temperature measurements, specific catalytic runs, and crystal structure determinations. CCDC 1437163 (2a), 1437165 (2b) and 1437164 (4). For ESI and crystallographic data in CIF or other electronic format see DOI: 10.1039/ c5dt04656d
}

for homogeneous catalysis, and with the emergence of $\mathrm{N}$-heterocyclic carbenes (NHCs) as a versatile class of strong $\sigma$-donating ligands for transition metals, ${ }^{8}$ a combination of the two scaffolds is a logical field for investigation. For example, the replacement of one or more of the pyridine units with an NHC fragment, ${ }^{9}$ such as in bipy ${ }^{10}$ and terpy ${ }^{11}$ ligand systems, has been investigated. Another strategy involves fusing an NHC onto a pyridyl group such as that of a phenanthroline ${ }^{12}$ or bipyridine ${ }^{13}$ unit, which gives inter alia the CNN analogue of a catalytically very active PNN pincer-type ligand. Complexes incorporating these ligands, specifically complexes of $\mathrm{Ru}$, are active catalysts for the hydrogenation of amides to alcohols. ${ }^{14}$ Much work in ruthenium polypyridine and NHC chemistry has surely been spurred by the advances made in both materials development and photochemistry. This latter aspect is a result of the fact that pyridyl-bound metal centres are, in particular, very useful for the conversion of light to energy and for the fabrication of supramolecular assemblies. ${ }^{15}$ Some recent reviews have covered the use of NHC ligands in transition metal complexes as components for materials science applications. ${ }^{16}$ While fused pyridyl-NHC metal complexes have attracted much interest, ${ }^{10,11,17}$ pyridyl and NHC ligands bound independent of each other to the metal centre have been less investigated. ${ }^{18}$ Based on the established impact of poly-pyridine ligands, we were interested in exploring pyridyl donors as ligands in conjunction with a chelating 
C4-diimidazolylidene rhodium(III) scaffold for transfer hydrogenation catalysis. ${ }^{19}$ Such abnormal or mesoionic ligands ${ }^{20}$ are strongly donating and have shown to enhance the catalytic activity of the metal center in several cases. ${ }^{21}$ In the set-up designed here, the chelating dicarbene and bipyridyl ligands bound to $\mathrm{Rh}$ leave two flexible sites available for possible hydride ligation and substrate interaction. On the other hand, terpy typically binds in a meridional $\kappa^{3}-N, N^{\prime}, N^{\prime \prime}$ coordination mode, which would leave only a single site available for substrate interaction, likely situated trans to one carbene bonding site. The strong trans effect of the carbene offers potential to enhance activity, such as by accelerating the product dissociation step in the catalytic cycle. Thus, we aimed at exploring bipy and terpy as ligands to furnish an active $\mathrm{Rh}$ (dicarbene) scaffold for transfer hydrogenation catalysis.

\section{Results and discussion}

\section{Synthesis of dicarbene pyridyl complexes}

Compound 1, a mono-cationic formal $\left[\mathrm{Rh}^{3+}\right]_{2}$ dimeric complex, was synthesised as previously described in the literature. ${ }^{22}$ Coordination of bipy, phen or terpy resulted in cleavage of the dimeric structure of $\mathbf{1}$ to give the bench-stable monometallic species 2, 3, and 4, respectively (Scheme 1).

The ${ }^{1} \mathrm{H}$ NMR spectroscopic data indicated only one set of bipy signals for 2 which suggests a $C_{2 \mathrm{v}}$-symmetric complex in solution, in which the bipy $\mathrm{N}$-atoms are in trans position to the carbene carbons. The ${ }^{1} \mathrm{H}$ NMR signals of the bipy display characteristic downfield shifts due to the reduced electron density about bipy when donating electron density to the Rh centre. For example, the protons ortho to the bipy nitrogens shift from $\delta_{\mathrm{H}}=8.66$ (free bipy) to $9.35 \mathrm{ppm}$ in $2 \mathrm{a}$ (both in $\mathrm{CD}_{2} \mathrm{Cl}_{2}$ ). The $\mathrm{NCH}_{2} \mathrm{~N}$ bridge and the iPr methyl groups of the

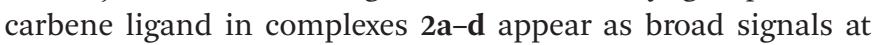
room temperature (RT) indicating slow inversion of the boat-

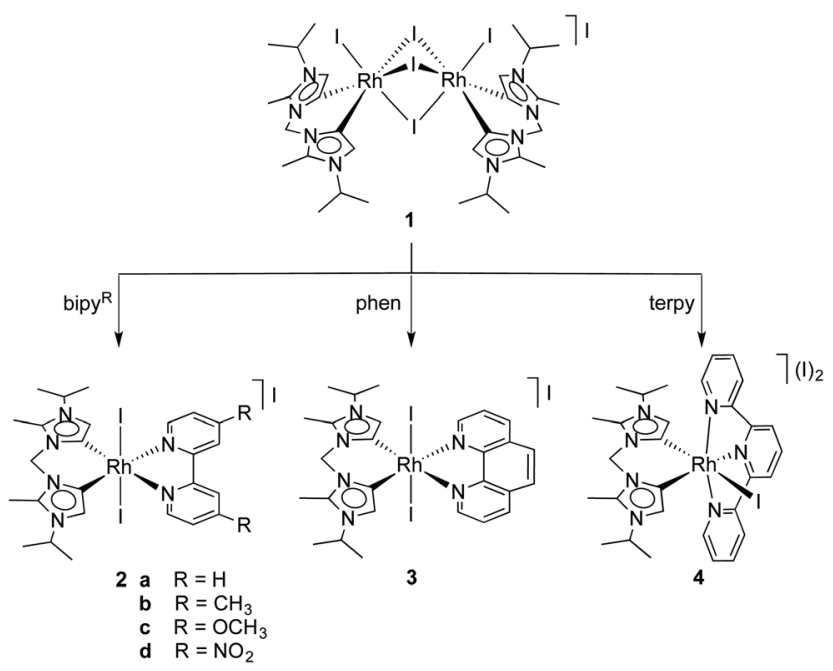

Scheme 1 Synthesis of dicarbene rhodium(III) complexes 2-4 bearing bipy, phen or terpy ligands. like metallacycle on the NMR timescale. The signals were well resolved on cooling the sample to $-20{ }^{\circ} \mathrm{C}$ and completely coalesce to a broad singlet upon heating to about $60{ }^{\circ} \mathrm{C}$ $\left(\mathrm{CD}_{3} \mathrm{CN}\right)$. From the coalescence temperature $\left(T_{\mathrm{c}}\right)$, the free energy of inversion $\left(\Delta G^{\star}\right)$ for the dicarbene metallacycle was estimated at $63 \pm 1 \mathrm{~kJ} \mathrm{~mol}^{-1}$ for $2 \mathrm{a}$ and identical within experimental error at $62 \pm 1,61 \pm 1$ and $61 \pm 1 \mathrm{~kJ} \mathrm{~mol}^{-1}$ for $2 \mathbf{b}-\mathbf{d}$, respectively. Calculating the free energy of inversion based on the $T_{\mathrm{c}}$ of the iPr methyl groups gave values within the standard deviation and are thus identical to the $\Delta G^{\ddagger}$ calculations based on the coalescence of the $\mathrm{NCH}_{2} \mathrm{~N}$ resonances. The substituent on the bipy backbone has a direct effect on the chemical shift of the bipy protons. The ortho bipy protons of $2 \mathrm{c}\left(\delta_{\mathrm{H}}=9.12\right)$, with the electron-donating methoxy group, are more shielded than for $2 \mathbf{a}\left(\delta_{\mathrm{H}}=9.38\right)$ while those of $2 \mathbf{d}$, with electron-withdrawing $-\mathrm{NO}_{2}$ substituents are significantly more deshielded $\left(\delta_{\mathrm{H}}=9.70 ; \mathrm{CD}_{3} \mathrm{CN}\right)$.

Tuning of the electron density about Rh, by incorporating electron-donating or electron-withdrawing groups at the para position of the pyridine ring was suggested by NMR spectroscopic analyses of the $\mathrm{C}_{\text {imid }}-\mathrm{H}$ proton resonances (Table 1). Albeit weak, the observed shift differences are diagnostic. Thus when compared to $2 \mathbf{a}\left(\delta_{\mathrm{H}}=7.29\right)$, this signal shifts upfield when an electron-donating substituent is incorporated (methyl; methoxy: $\delta_{\mathrm{H}}=7.26 ; 7.23$ ), and it is more deshielded in 2d featuring an electron-withdrawing nitro group $\left(\delta_{\mathrm{H}}=\right.$ 7.32). Similarly, the ${ }^{13} \mathrm{C}$ NMR signals for the metal-bound carbenic nucleus $\mathrm{C}_{\text {imid }}-\mathrm{Rh}$ were slightly more deshielded in $\mathbf{2 b}$ and $2 \mathrm{c}\left(\delta_{\mathrm{C}}=137.6, \mathrm{R}=\mathrm{Me}\right.$, and 137.9, $\mathrm{R}=\mathrm{OMe}$, respectively) when compared to $2 \mathbf{a}\left(\delta_{\mathrm{C}}=137.4\right)$. This nucleus is considerably more shielded in $2 \mathbf{d}\left(\delta_{\mathrm{C}}=135.3\right)$. These data suggest that the electronics of the $\mathrm{Rh}$ centre can be finely modulated without affecting the steric environment about the metal center. Interestingly, though, the Rh-C coupling constants were not sensitive to the modulated donor properties of the trans-positioned bipy. Much like the activation energy for metallacycle inversion (see above), no clear trend was apparent in complexes $\mathbf{2 a - d}$ for the $\mathrm{Rh}-\mathrm{C}$ coupling constants $\left(J_{\mathrm{CRh}}=36.9 \pm 0.4 \mathrm{~Hz}\right)$.

The phen complex 3 showed generally more deshielded ${ }^{1} \mathrm{H}$ NMR resonances compared to those of $2 \mathbf{a}$, including a lower field signal for the $\mathrm{C}_{\mathrm{imid}}-\mathrm{H}$ protons $\left(\delta_{\mathrm{H}}=7.42\right)$. The $\mathrm{NCH}_{2} \mathrm{~N}$ and iPr methyl proton signals also appeared as broad multiplets at RT indicating slow inversion of the dicarbene metallacycle.

For the terpyridine complex $\mathbf{4}$, desymmetrisation of the complex was apparent by the two inequivalent sets of ${ }^{1} \mathrm{H}$ and ${ }^{13} \mathrm{C}$ NMR signals for the dicarbene ligand. For example, the

Table $1{ }^{1} \mathrm{H}$ and ${ }^{13} \mathrm{C}$ NMR data and free energy of dicarbene metallacycle inversion for complexes $2 a-d$ (in $C_{3} C N$ )

\begin{tabular}{lllll}
\hline Complex & $\mathrm{C}_{\text {imid }}-\mathrm{H}(\mathrm{ppm})$ & $\mathrm{C}_{\text {imid }}(\mathrm{ppm})$ & $J_{\mathrm{CRh}}(\mathrm{Hz})$ & $\Delta G_{\text {av }}\left(\mathrm{kJ} \mathrm{mol}^{-1}\right)$ \\
\hline 2a & 7.29 & 137.4 & 36.5 & $63 \pm 1$ \\
2b & 7.26 & 137.6 & 36.8 & $62 \pm 1$ \\
2c & 7.23 & 137.9 & 36.8 & $61 \pm 1$ \\
2d & 7.32 & 135.3 & 37.3 & $61 \pm 1$
\end{tabular}


two carbene $C$-atoms for 4 resonate at $\delta_{\mathrm{C}}=141.0\left({ }^{1} J_{\mathrm{CRh}}=\right.$ $38.5 \mathrm{~Hz})$ and $133.2\left({ }^{1} J_{\mathrm{CRh}}=42.1 \mathrm{~Hz}\right) \mathrm{ppm}$. Likewise, in the ${ }^{1} \mathrm{H}$ NMR spectrum, the $\mathrm{C}-\mathrm{CH}_{3}$ signals appeared as two singlets at $\delta_{\mathrm{H}}=2.91$ and 2.61 each integrating for three protons. The $\mathrm{C}_{\text {imid }}$ protons were significantly separated $\left(\delta_{\mathrm{H}}=7.68,5.89\right)$. The higher field resonance indicates a significant shielding effect of the terpy $\pi$-system on the proximal imidazolylidene proton, while the more distant imidazolylidene proton showed a more typical resonance value. Inversion of the metallacycle is more facile in $\mathbf{4}$ than in complexes $\mathbf{2 a}-\mathbf{d}$ since the methylene linker appears as a singlet resonance at $\delta_{\mathrm{H}}=6.02$.

\section{X-ray crystallography}

Structural data was obtained for complexes 2a, 2b and $\mathbf{4}$ from X-ray diffraction studies (Fig. 1) which unambiguously confirmed that both bipy $N$-atoms are trans to a carbene in complexes $2 \mathbf{a} / \mathbf{b}$. Selected bond lengths and angles are shown in Table 2. For these two compounds, the $\mathrm{Rh}$ atom resides in a slightly distorted octahedral geometry comprised of the dicarbene ligand, bipy and two iodido ligands in a mutually trans arrangement. The dicarbene rhodacycle adopts a boat-type geometry in the solid state. The average Rh-C bond length of $2.013 \AA$ is within the expected range, ${ }^{23}$ and slightly longer than that found in related $\mathrm{Rh}$ (III) complexes which bear two acetonitrile ligands instead of a chelating bipy (average $\mathrm{Rh}-\mathrm{C}=$ $1.985 \AA$ A). ${ }^{22}$ The $\mathrm{Rh}-\mathrm{N}$ bond lengths for $2 \mathbf{b}$ are slightly longer than those of $2 \mathrm{a}$ perhaps pointing to an electronic effect of the
Table 2 Selected bond lengths $(\AA)$ and angles $\left(^{\circ}\right)$ for $2 a, 2 b$ and 4

\begin{tabular}{llll}
\hline & $2 \mathbf{a}(\mathrm{X}=\mathrm{I} 2)$ & $2 \mathbf{b}(\mathrm{X}=\mathrm{I} 2)$ & $\mathbf{4}(\mathrm{X}=\mathrm{N} 7)$ \\
\hline Rh-C1 & $2.011(2)$ & $2.024(5)$ & $2.026(5)$ \\
Rh-C9 & $2.006(2)$ & $2.011(2)$ & $2.011(5)$ \\
Rh-N5 & $2.1273(18)$ & $2.145(4)$ & $2.062(5)$ \\
Rh-N6 & $2.1263(17)$ & $2.131(4)$ & $1.998(4)$ \\
Rh-I1 & $2.6543(2)$ & $2.6505(5)$ & $2.7464(5)$ \\
Rh-X & $2.6810(2)$ & $2.6943(5)$ & $2.066(5)$ \\
C1-Rh-C9 & $84.14(8)$ & $85.31(18)$ & $87.0(2)$ \\
C1-Rh-N6 & $174.95(8)$ & $175.56(18)$ & $177.8(2)$
\end{tabular}

more electron-donating 4,4'- $\mathrm{Me}_{2}$-bipy ligand. For $\mathbf{4}$, the meridionally binding terpy ligand restricts coordination of the iodido ligand to the position trans to the carbene. The Rh-I bond length of 2.7464(5) $\AA$ is longer than those of 2 (average Rh-I = 2.670 ̊), highlighting the strong trans influence of the carbene ligand. The Rh-C bond lengths are identical within standard deviations and thus suggest that the iodine and the pyridine $\mathrm{N}$-atoms have a similar trans influence. ${ }^{24}$ Meridional binding of the terpy ligand in $\mathbf{4}$ allows for an almost ideal dicarbene bite angle to $\mathrm{Rh}\left(\mathrm{C}-\mathrm{Rh}-\mathrm{C} 87.0(2)^{\circ}\right)$. However, distortion from octahedral geometry is apparent by the N5-Rh-N7 angle of $159.73(19)^{\circ}$. Of note, the proton bound to $\mathrm{C} 10$ is rather close to the central pyridyl ring $\left(\mathrm{H} 10 \cdots \mathrm{Cg}_{\mathrm{pyr}} 3.30 \AA\right.$ ), which is in agreement with a strong shielding of that proton in the ${ }^{1} \mathrm{H}$ NMR spectrum due to ring current effects.
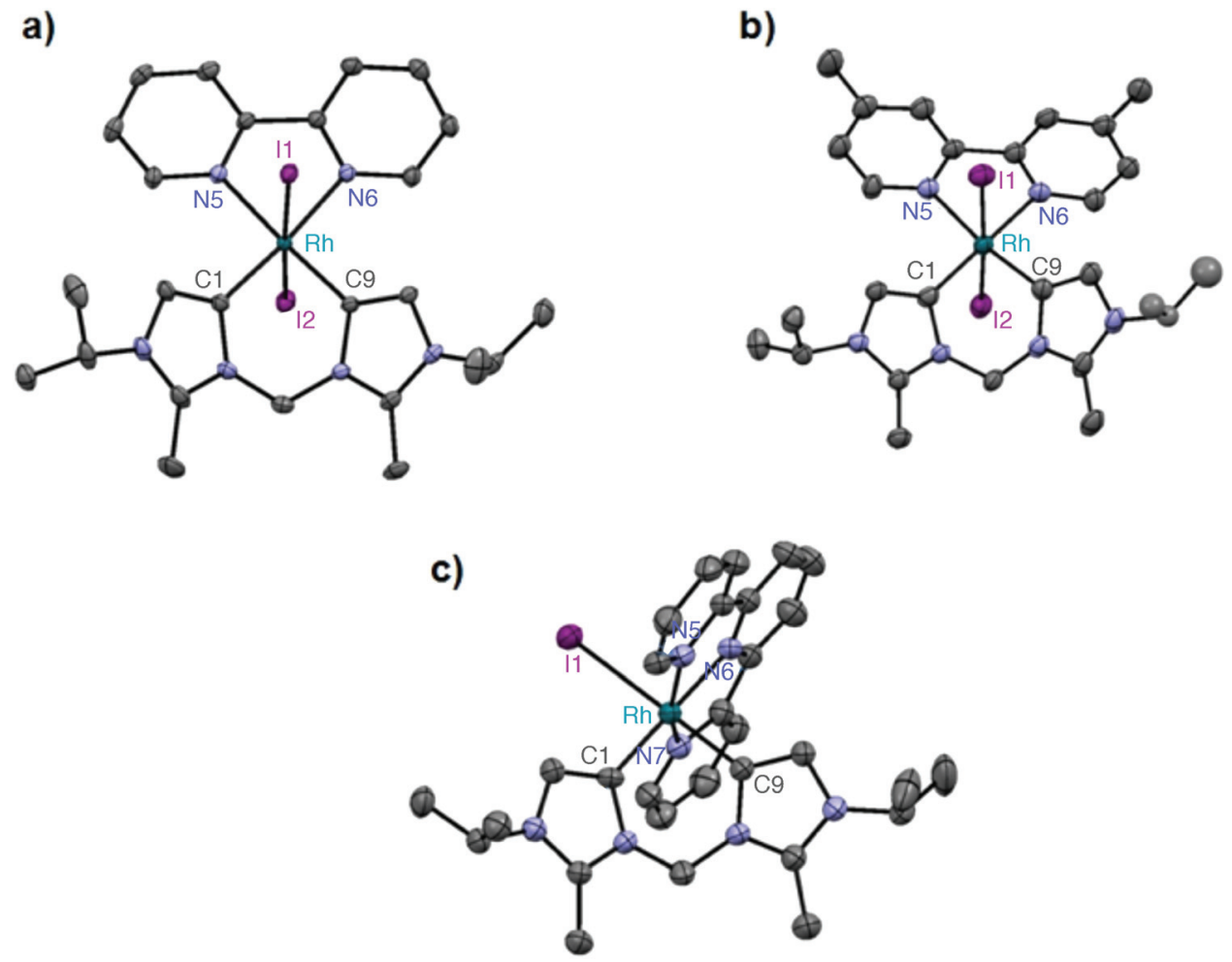

Fig. 1 ORTEP representation of the cationic portions of $2 a(a), 2 b$ (b) and 4 (c). Ellipsoids are drawn on the 50\% probability level. Hydrogen atoms and co-crystallised solvent molecules have been omitted for clarity. 


\section{Catalytic transfer hydrogenation}

The activity of complexes 2, 3 and 4 in hydrogen transfer catalysis was evaluated using 2-propanol as the formal $\mathrm{H}_{2}$ donor and benzophenone as a model acceptor (Table 3). ${ }^{25}$ Typically, the active catalyst was formed by heating the precursor complex in basic iPrOH to reflux temperature for $10 \mathrm{~min}$ before benzophenone was added. At 0.15 mol\% catalyst loading, most imine complexes showed enhanced catalytic activity when compared to dimer 1 . The latter gave $50 \%$ conversion after $2 \mathrm{~h}$ and did not reach full conversion after $24 \mathrm{~h}$ ( $82 \%$, entry 1 ). Complex $2 \mathbf{a}$ and $2 \mathbf{b}$ were significantly more active and afforded hydrogenated diphenylmethanol in quantitative yields after 2 and $3 \mathrm{~h}$, respectively (entries 2 and 3). Tuning of the catalytic activity was expected by incorporation of electronically active groups on the bipy backbone. Intriguingly, modification of the bipy by incorporating electron-donating or withdrawing groups resulted in poorer conversions than 2a (which contains a $\mathrm{H}$-atom in the bipy para positions). A methyl group at the para position of the pyridine ring slowed the catalysis compared to $\mathbf{2 a}$ which is particularly evident at early onset reaction times (entry 3 ). Much more detrimental was heteroatom substitution at the 4,4'-position of bipy as shown by $2 \mathbf{c}$ and $\mathbf{2 d}$, which both gave only very poor conversion values (entries 4 and 5). The more rigid diimine system 3 led to a catalyst with similar activity to $\mathbf{2 a}(c f$. entry 6 ). In contrast, complex 4 containing a terpy ligand was slower than 2a and showed essentially the same activity as the imine free dimer $\mathbf{1}$ and full conversion was only reached at prolonged reaction times (entry 7). Presumably the availability of only one site for substrate coordination decelerates catalytic turnovers. It is worth noting that while the diimine ligand does accelerate the transfer hydrogenation catalysis ( $c f$. entries 1 and 2), the activity is less enhanced than when incorporating

Table 3 Catalytic transfer hydrogenation of benzophenone with rhodium(III) dicarbene pyridyl complexes ${ }^{a}$

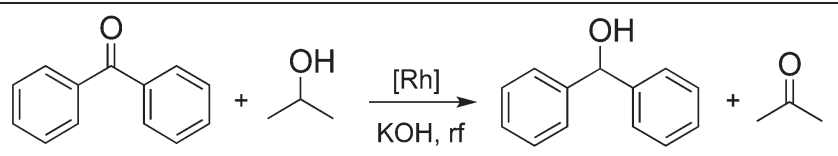

\begin{tabular}{|c|c|c|c|c|c|c|}
\hline \multirow[b]{2}{*}{ Entry } & \multirow[b]{2}{*}[\mathrm{Rh}]{} & \multirow[b]{2}{*}{ Mol\% [Rh] } & \multicolumn{3}{|c|}{ Conversion } & \multirow[b]{2}{*}{ TON } \\
\hline & & & $0.5 \mathrm{~h}$ & $2 \mathrm{~h}$ & $3 \mathrm{~h}$ & \\
\hline 1 & 1 & 0.15 & 26 & 50 & $82^{b}$ & 330 \\
\hline 2 & $2 a$ & 0.15 & 26 & 97 & 99 & 660 \\
\hline 3 & $2 b$ & 0.15 & 9 & 70 & 97 & 650 \\
\hline 4 & $2 c$ & 0.15 & 8 & 34 & 50 & 330 \\
\hline 5 & $2 d$ & 0.15 & 17 & 47 & 66 & 440 \\
\hline 6 & 3 & 0.15 & 22 & 97 & 100 & 670 \\
\hline 7 & 4 & 0.15 & 22 & 56 & $93^{b}$ & 620 \\
\hline 8 & - & - & $<2$ & $<2$ & $<2$ & 一 \\
\hline
\end{tabular}

${ }^{a}$ General conditions: benzophenone ( $\left.3 \mathrm{mmol}\right)$, iPrOH $(15 \mathrm{~mL}), \mathrm{KOH}$ $(0.3 \mathrm{mmol})$, reflux temperature. $\mathrm{KOH}$ was added as a $2 \mathrm{M}$ aqueous solution; conversions and yields identical, averages of at least two runs with deviations of $\max \pm 3 \%$ except entry 5 , deviation $\max 10 \%$. ${ }^{b}$ Conversion after $24 \mathrm{~h}$. diphosphine ligands. ${ }^{26}$ Related rhodium systems containing a dicarbene ligand scaffold are considerably less active. ${ }^{27}$

Interestingly, formation of the catalytically active species during the substrate-free initiation period was indicated by a distinct colour change of the reaction mixture from yellow to deep purple (complexes 2 and 3, Fig. 2) or bright green (for 4). When using the less active complexes $2 \mathbf{c}$ and $\mathbf{2 d}$, a colour change to reddish/brown was observed after heating to reflux in the presence of $\mathrm{KOH}$ (10 min.). After full conversion of benzophenone, the colour of the reaction mixtures remained purple for some time, and changed back to yellow only after extended periods of stirring. The same colour change was observed upon cooling the reaction mixtures at partial conversion. With further heating (to induce full conversion), the purple colour was again established. These observations suggest that the purple colour is associated with a compound that only persists at elevated temperatures and that is related to the catalytically active species. The yellow colour is thus diagnostic of a dormant state of the catalyst derived from $2 \mathbf{a}$, while the purple species is correlated with catalytic activity. This colour change reveals a useful diagnostic tool to evaluate the status of the catalytic reaction for all the complexes 2-4. Accordingly, the catalyst remains in its active form even after full consumption of the substrate, but gradually deactivates after full conversion, as indicated by the colour change from purple back to yellow after extended periods of stirring ( $>10$ h) when full conversion was reached. Presumably, evaporation of acetone prohibits a steady state hydrogen transfer equilibrium.

To further investigate the nature of the active species, a series of temperature- and solvent-dependent experiments were performed to identify the source of the colour change. The purple species was only observed in solvents such as iPrOH and cyclohexanol which contain a H-atom $\alpha$ to that of

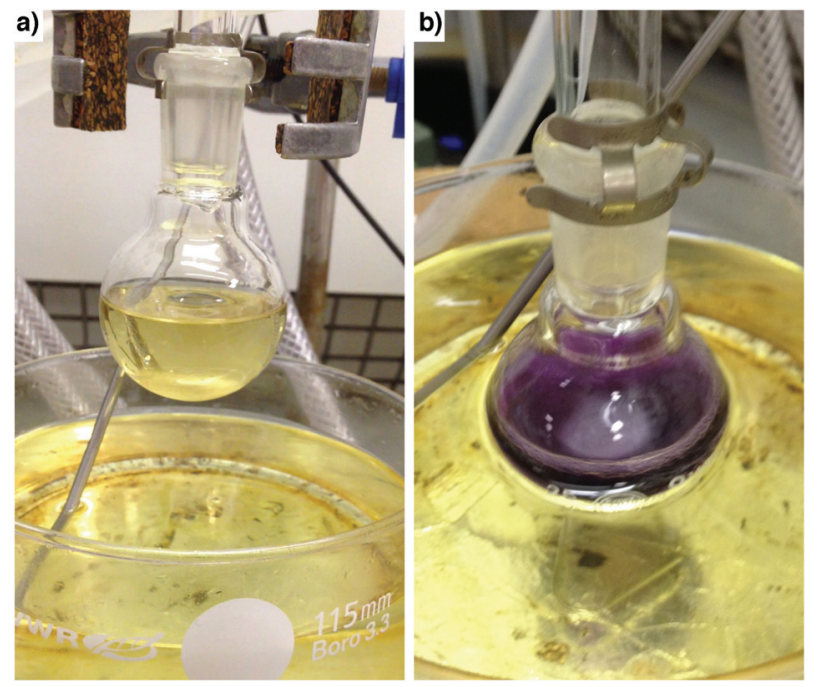

Fig. 2 Colour change of solutions containing the dormant catalytically inactive form derived from complex 2a (a; yellow solution), and the catalytically active form (b; purple solution). 
the alcohol group. When using $t \mathrm{BuOH}$, with $\mathrm{KOH}$ as base, or in 1,2-dichloroethane at reflux temperature, no colour change of 2a nor any catalytic hydrogen transfer was observed. Similarly, no colour change was observed when 2 a was refluxed in $\mathrm{iPrOH}$ without $\mathrm{KOH}$. Therefore, the colour change is probably not associated with the formation of an alkoxide species and may originate instead from a hydride complex that is formed after $\beta$-hydride elimination of the alkoxide. ${ }^{28}$ Indeed, catalytic transfer hydrogenation with 2 a can also be carried out with cyclohexanol as the $\mathrm{H}_{2}$ source. At $160{ }^{\circ} \mathrm{C}, 24 \%$ conversion of benzophenone to diphenylmethanol was reached after $4 \mathrm{~h}$ and the solution mixture was again purple in colour. In a parallel run in cyclohexanol at $110{ }^{\circ} \mathrm{C}$ (i.e., the typical temperature used for transfer hydrogenation with iPrOH), the mixture remained yellow throughout and was essentially inactive $(<5 \%$ conversion after $4 \mathrm{~h}$ ). These temperature dependent studies support the fact that the purple species only forms at vigorous reflux, possibly to advance the $\beta$-hydride elimination from the alkoxide by removal of the corresponding ketone.

The colour-activity relationship and the robustness of the active species derived from $\mathbf{2 a}$ were utilised in a recycling experiment. To this end, a reaction was launched with the same substrate/base/catalyst ratio $(6 \mathrm{mmol}$ benzophenone, $0.15 \mathrm{~mol} \% 2 \mathrm{a}, 30 \mathrm{~mL}$ iPrOH) and every 2.5 hours, conversions were determined and a fresh batch of benzophenone ( $6 \mathrm{mmol}$ ) was added (Fig. 3). The conversions, were high for each addition of benzophenone (typically $>90 \%$ ) and the reaction mixture remained active and purple in colour over five consecutive additions of substrate. The fifth batch was stirred for 14 rather than just $2.5 \mathrm{~h}$, and while this extended reaction time did not affect yields (overall $>92 \%$ ), the colour of the solution changed back to yellow during this period. Addition of a sixth batch of benzophenone did not lead to significant conversions anymore and the catalytic activity effectively ceased. Thus, an overall yield of $92 \%$ (30 mmol benzophenone) and a turnover number (TON) of 3100 over five batches of benzophenone was achieved with $2 \mathbf{a}$. Similarly high turnovers have been

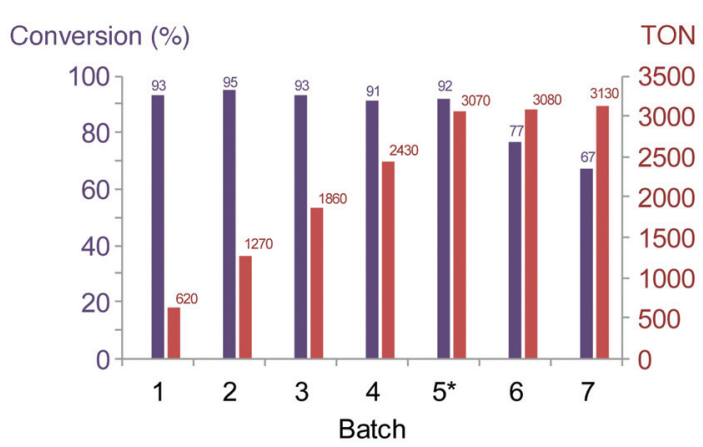

Fig. 3 Repetitive addition of benzophenone for transfer hydrogenation using $2 \mathrm{a}$ showing total conversion (purple, determined $2.5 \mathrm{~h}$ after addition of benzophenone) and aggregated turnover number (TON, red). Benzophenone was added every $2.5 \mathrm{~h}$, except for the $6^{\text {th }}$ batch, which was added only after $14 \mathrm{~h} \mathrm{(*).}$

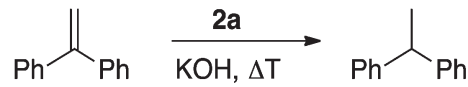

Scheme 2 Transfer hydrogenation of 1,1-diphenylethylene with $2 a$.

obtained with rhodium complexes containing specific carbene spectator ligands. $^{29}$

Typically, the status of catalytic reactions can rarely be determined visually by simply monitoring the reaction mixture. For example, the imine-free complex $\mathbf{1}$ or related dicarbene $\mathrm{Rh}(\mathrm{III})$ complexes containing diphosphine spectator ligands displayed no colour changes throughout the same transfer hydrogenation catalysis. ${ }^{26}$ The colour change observed in this work appears to be specific to complexes 2, 3 and 4 and probably involves in some way the pyridyl ligand, perhaps by a hydride migration process. Chirik and co-workers have observed ligand-centred radicals and migration of hydrides and alkyl groups to the 4-position of a metal-bound pyridine unit in a cobalt complex. ${ }^{30}$ The lower conversions of the catalysis when incorporating substituents, whether electron-donating or -withdrawing, on the $4,4^{\prime}$-positions of the bipy ligand (2b-d) is unexpected and may hint at a similar involvement of the pyridine unit in complexes $\mathbf{2 a - d}$. Hence, hydride migration from the Rh centre to the bipy may occur and may be more sterically hindered in the case of $\mathbf{2} \mathbf{b}-\mathbf{c}$ when compared to that of $2 \mathbf{a}$. In an attempt to probe such a migration, a catalytic run with the deuterated hydrogen donor $\left(\mathrm{CD}_{3}\right)_{2} \mathrm{CDOH}$ as solvent was carried out. Approximately 91\% deuterium incorporation was noted at the carbinol carbon of the formed diphenylmethanol, thus indicating a monohydride mechanism for the hydrogen transfer. ${ }^{31}$ The $\mathrm{Rh}$ species recovered at the end of the process did not reveal any deuterium incorporation into the aromatic region $\left({ }^{2} \mathrm{H}\right.$ NMR spectroscopy). In another attempt to determine if migration to the 4-position of bipy was occurring, a standard catalytic run was set up with 2 a and using 1,1-diphenylethylene as substrate which may migrate to the pyridyl ligand. ${ }^{30}$ While full conversion to the corresponding alkane was observed after $14 \mathrm{~h}$, no migrated pyridylbound alkyl species was detected by either NMR spectroscopy or mass spectrometry. Even though these experiments thus do not provide any further mechanistic insights, they demonstrate that complex 2a is also an efficient catalyst for transfer hydrogenation of hydrocarbon olefins (Scheme 2). ${ }^{32}$ Hence, bipy coordination is an attractive extension for Rh-catalysed hydrogen transfer catalysis as this ligand enhances the catalytic performance of the metal centre and offers a convenient visual indicator of the catalytic activity.

\section{Conclusions}

A series of air-stable pyridyl coordinated formally Rh(III) dicarbene complexes, bearing bipy, phen or terpy, have been synthesised in high yields and utilised for transfer hydrogenation in $\mathrm{iPrOH} / \mathrm{KOH}$. Pyridyl ligand incorporation enhances the 
activity of the dicarbene rhodium(III) system for this hydrogenation involving benzophenone at low catalyst loadings (0.15 mol\%). The active species display a visual signature for determining the status of the reaction based on a vivid colour change (yellow to purple or green) upon activation. Temperature and solvent-dependent studies indicate that the colour change is probably associated with a $\mathrm{Rh}-\mathrm{H}$ species formed following $\beta$-hydride elimination of a coordinated alkoxide at elevated temperatures during the catalytic cycle. The correlation between the colour of the reaction and the catalytically active species is unusual and offers further potential in catalysis investigations. For example, sampling of the catalytic reaction is often disruptive to the reaction rate and may be circumvented using the UV-Vis properties rather than intrusive sampling. The colour of the reaction enables a visual determination of whether the catalytically active species still persists and is thus particularly useful for recycling experiments. Incorporation of aliphatic diamines or diimines to the dicarbene $\mathrm{Rh}(\mathrm{III})$ platform, rather than aromatic diimines reported here, may shed further light on the source of the colour change on catalyst activation.

\section{Experimental section}

\section{General comments}

All syntheses were carried out under ambient conditions unless otherwise stated and all reagents and solvents were used as received from commercial suppliers. The diimidazolium salt and complex 1 were prepared according to literature procedures. ${ }^{22}$ Unless specified, ${ }^{1} \mathrm{H}$ and ${ }^{13} \mathrm{C}\left\{{ }^{1} \mathrm{H}\right\}$ NMR spectra were recorded at $25{ }^{\circ} \mathrm{C}$ on Varian spectrometers operating at $300,400,500$ or $600 \mathrm{MHz}\left({ }^{1} \mathrm{H} \mathrm{NMR}\right)$ and 101,126 or $151 \mathrm{MHz}$ $\left({ }^{13} \mathrm{C}\right.$ NMR) respectively. Chemical shifts $(\delta$ in ppm, coupling constants $J$ in $\mathrm{Hz}$ ) were referenced to residual solvent signals $\left({ }^{1} \mathrm{H},{ }^{13} \mathrm{C}\right)$. Assignments are based on homo- and heteronuclear shift correlation spectroscopy. Elemental analyses were performed at UCD Microanalytic Laboratory using an Exeter Analytical CE-440 elemental analyser. High-resolution mass spectrometry was carried out with a Micromass/Waters Corp. USA liquid chromatography with an electrospray source. RT is $18^{\circ} \mathrm{C}$ unless otherwise stated.

\section{General procedure for the synthesis of complexes $2 a-d$, 3 and 4}

The dimeric complex 1 was dissolved in $\mathrm{CH}_{2} \mathrm{Cl}_{2}(20 \mathrm{~mL})$ and the relevant pyridyl compound was added (2.2 equiv.:1.1 equiv. per $\mathrm{Rh}$ atom). The solution was stirred for $16 \mathrm{~h}$ at RT. The resulting suspension was added to a centrifuge vessel with $\mathrm{Et}_{2} \mathrm{O}(80 \mathrm{~mL})$ and the precipitate was then isolated by centrifugation and decantation. The orange residue was re-dissolved $\left(\mathrm{CH}_{2} \mathrm{Cl}_{2}: 10 \mathrm{~mL}\right)$ and precipitated again with $\mathrm{Et}_{2} \mathrm{O}(80 \mathrm{~mL})$. Following centrifugation and decantation of the supernatant, the recovered residue was dried under reduced pressure to yield the pure product.
[RhI 2 (C,C-dicarbene)(2,2'-dipyridyl)]I (2a). Following the general procedure, complex 1 (200 $\mathrm{mg}, 0.13 \mathrm{mmol}$ ) and 2,2'bipyridine (42 mg, $0.27 \mathrm{mmol}$ ) afforded 2a (190 mg, 78\%) as a yellow coloured solid. Crystals of 2a for X-ray diffraction studies were grown by slow evaporation of an MeCN solution of the complex. ${ }^{1} \mathrm{H}$ NMR $\left(253 \mathrm{~K}, 600 \mathrm{MHz}, \mathrm{CD}_{3} \mathrm{CN}\right): \delta=9.38$ (d, $\left.2 \mathrm{H},{ }^{3} J_{\mathrm{HH}}=5.3 \mathrm{~Hz}, \mathrm{H}_{\text {bipy-6}}\right), 8.49\left(\mathrm{~d}, 2 \mathrm{H},{ }^{3} J_{\mathrm{HH}}=8.1 \mathrm{~Hz}, \mathrm{H}_{\text {bipy-3}}\right)$, 8.13 (m, 2H, $\mathrm{H}_{\text {bipy-4 }}$ ), 7.74 (m, 2H, $\mathrm{H}_{\text {bipy-5 }}$ ), 7.29 (s, 2H, $\mathrm{H}_{\text {imid }}$ ), $6.99\left(\mathrm{~d}, 1 \mathrm{H},{ }^{2} J_{\mathrm{HH}}=13.1 \mathrm{~Hz}\right.$, lowfield $\mathrm{AB}$ part of $\left.\mathrm{NCH}_{2} \mathrm{~N}\right), 6.15$ $\left(\mathrm{d}, 1 \mathrm{H},{ }^{2} J_{\mathrm{HH}}=13.1 \mathrm{~Hz}\right.$, highfield $\mathrm{AB}$ part of $\left.\mathrm{NCH}_{2} \mathrm{~N}\right), 4.57$ (septet, $\left.2 \mathrm{H},{ }^{3} J_{\mathrm{HH}}=6.6 \mathrm{~Hz}, \mathrm{NCH}(\mathrm{Me})_{2}\right), 2.70\left(\mathrm{~s}, 6 \mathrm{H}, \mathrm{C}_{\text {imid }}-\mathrm{CH}_{3}\right.$ ), $1.62,1.40\left(\mathrm{~d}, 6 \mathrm{H},{ }^{3} J_{\mathrm{HH}}=6.6 \mathrm{~Hz}, \mathrm{NCH}\left(\mathrm{CH}_{3}\right)_{2}\right) .{ }^{13} \mathrm{C} \mathrm{NMR}(253 \mathrm{~K}$, $\left.151 \mathrm{MHz}, \mathrm{CD}_{3} \mathrm{CN}\right): \delta=156.1\left(\mathrm{C}_{\text {bipy-2}}\right), 152.4\left(\mathrm{C}_{\text {bipy-6}}\right), 141.8$ $\left(\mathrm{NC}_{\text {imid }} \mathrm{N}\right), 139.2\left(\mathrm{C}_{\text {bipy-4}}\right), 137.4\left(\mathrm{~d},{ }^{1} J_{\mathrm{CRh}}=36.5 \mathrm{~Hz}, \mathrm{C}_{\text {imid }}-\mathrm{Rh}\right)$, $127.11\left(\mathrm{C}_{\text {bipy-5 }}\right), 124.0\left(\mathrm{C}_{\text {bipy-3 }}\right), 123.9\left(\mathrm{C}_{\text {imid }}-\mathrm{H}\right), 61.2\left(\mathrm{NCH}_{2} \mathrm{~N}\right)$, $50.5\left(\mathrm{CH}(\mathrm{Me})_{2}\right), 22.2,22.1\left(\mathrm{CH}\left(\mathrm{CH}_{3}\right)_{2}\right), 10.5\left(\mathrm{C}_{\text {imid }}-\mathrm{CH}_{3}\right)$. ESI-MS $(m / z): ~ 772.9813$, calcd for $[\mathrm{M}-\mathrm{I}]^{+}$772.9833. Anal. calcd for $\mathrm{C}_{25} \mathrm{H}_{32} \mathrm{I}_{3} \mathrm{~N}_{6} \mathrm{Rh}$ (900.18)·0.75 $\mathrm{CH}_{2} \mathrm{Cl}_{2}$ : C, 32.09; H, 3.50; $\mathrm{N}$, 8.72. Found: C, 32.30; H, 3.17; N, 8.38.

[RhI ${ }_{2}$ (C,C-dicarbene)(4,4'-dimethyl-2,2'-dipyridyl)]I (2b). Following the general procedure 1 (70 $\mathrm{mg}, 0.047 \mathrm{mmol}$ ) and 4,4'dimethyl-2,2'-bipyridine (18 $\mathrm{mg}, 0.098 \mathrm{mmol}$ ) afforded $2 \mathbf{b}$ (58 $\mathrm{mg}, 42 \%)$ as a yellow coloured solid. No precipitate was observed after the reaction, however addition of $\mathrm{Et}_{2} \mathrm{O}(70 \mathrm{~mL})$ induced precipitation of the product in the form of an orange coloured solid. Crystals of $\mathbf{2} \mathbf{b}$ for X-ray diffraction studies were obtained by slow diffusion of $\mathrm{Et}_{2} \mathrm{O}$ into a $\mathrm{CH}_{2} \mathrm{Cl}_{2}$ solution of the complex. ${ }^{1} \mathrm{H}$ NMR (253 K, $\left.500 \mathrm{MHz}, \mathrm{CD}_{3} \mathrm{CN}\right): \delta=9.19$ (d, $\left.2 \mathrm{H},{ }^{3} J_{\mathrm{HH}}=5.6 \mathrm{~Hz}, \mathrm{H}_{\text {bipy-6}}\right), 8.36\left(\mathrm{~s}, 2 \mathrm{H}, \mathrm{H}_{\text {bipy-3 }}\right), 7.56(\mathrm{~d}, 2 \mathrm{H}$, $\left.{ }^{3} J_{\mathrm{HH}}=5.6 \mathrm{~Hz}, \mathrm{H}_{\text {bipy-5}}\right), 7.26\left(\mathrm{~s}, 2 \mathrm{H}, \mathrm{H}_{\text {imid }}\right), 6.97\left(\mathrm{~d}, 1 \mathrm{H},{ }^{2} J_{\mathrm{HH}}=\right.$ $13.1 \mathrm{~Hz}$, lowfield $\mathrm{AB}$ part of $\left.\mathrm{NCH}_{2} \mathrm{~N}\right), 6.15\left(\mathrm{~d}, 1 \mathrm{H},{ }^{2} J_{\mathrm{HH}}=\right.$ $13.1 \mathrm{~Hz}$, highfield $\mathrm{AB}$ part of $\mathrm{NCH}_{2} \mathrm{~N}$ ), 4.57 (septet, $2 \mathrm{H},{ }^{3} \mathrm{~J}_{\mathrm{HH}}=$ $\left.6.6 \mathrm{~Hz}, \mathrm{NCH}(\mathrm{Me})_{2}\right), 2.70\left(\mathrm{~s}, 6 \mathrm{H}, \mathrm{C}_{\mathrm{imid}}-\mathrm{CH}_{3}\right), 2.60$ (s, 6H, $\mathrm{C}_{\mathrm{bipy}-4}{ }^{-}$ $\left.\mathrm{CH}_{3}\right) 1.61,1.40\left(\mathrm{~d}, 6 \mathrm{H},{ }^{3} J_{\mathrm{HH}}=6.6 \mathrm{~Hz}, \mathrm{NCH}\left(\mathrm{CH}_{3}\right)_{2}\right) .{ }^{13} \mathrm{C} \mathrm{NMR}$ $\left(253 \mathrm{~K}, 126 \mathrm{MHz}, \mathrm{CD}_{3} \mathrm{CN}\right): \delta=155.8\left(\mathrm{C}_{\text {bipy-2}}\right), 151.6\left(\mathrm{C}_{\text {bipy-6}}\right)$, $151.2\left(\mathrm{C}_{\text {bipy-4 }}\right), 141.8\left(\mathrm{NC}_{\text {imid }} \mathrm{N}\right), 137.6\left(\mathrm{~d},{ }^{1} J_{\mathrm{CRh}}=36.8 \mathrm{~Hz}\right.$, $\left.\mathrm{C}_{\text {imid }}-\mathrm{Rh}\right), 127.8$ ( $\left.\mathrm{C}_{\text {bipy-5}}\right), 124.7$ ( $\left.\mathrm{C}_{\text {bipy-3 }}\right), 123.9\left(\mathrm{C}_{\text {imid }}-\mathrm{H}\right), 61.1$ $\left(\mathrm{NC}_{\text {imid }} \mathrm{N}\right), 50.5\left(\mathrm{CH}(\mathrm{Me})_{2}\right), 22.1\left(\mathrm{CH}\left(\mathrm{CH}_{3}\right)_{2}\right), 20.9\left(\mathrm{C}_{\text {bipy-4}}-\mathrm{CH}_{3}\right)$ $10.5\left(\mathrm{C}_{\text {imid }}-\mathrm{CH}_{3}\right)$. ESI-MS $(\mathrm{m} / \mathrm{z}): 801.0116$, calcd for $[\mathrm{M}-\mathrm{I}]^{+}$ 801.0146. Anal. calcd for $\mathrm{C}_{27} \mathrm{H}_{36} \mathrm{I}_{3} \mathrm{~N}_{6} \mathrm{Rh}(928.23) \cdot 0.5 \mathrm{CH}_{2} \mathrm{Cl}_{2}$ : C, 34.03; H, 3.84; N, 8.66. Found: C, 34.04; H, 3.42; N, 8.59.

[RhI $\mathbf{R}_{2}(\mathrm{C}, \mathrm{C}$-dicarbene)(4,4'-dimethoxy-2,2'-dipyridyl)]I (2c). Following the general procedure, $1(50 \mathrm{mg}, 0.034 \mathrm{mmol})$ and 4,4'-dimethoxy-2,2'-bipyridine (15 $\mathrm{mg}, 0.069 \mathrm{mmol}$ ) afforded 2c (44 mg, 68\%) as an orange coloured solid. ${ }^{1} \mathrm{H}$ NMR (253 K, $\left.500 \mathrm{MHz}, \mathrm{CD}_{3} \mathrm{CN}\right): \delta=9.12\left(\mathrm{~d}, 2 \mathrm{H},{ }^{3} J_{\mathrm{HH}}=6.4 \mathrm{~Hz}, \mathrm{H}_{\text {bipy-6}}\right), 8.00$ $\left(\mathrm{d}, 2 \mathrm{H},{ }^{4} J_{\mathrm{HH}}=2.6 \mathrm{~Hz}, \mathrm{H}_{\text {bipy-3}}\right), 7.29\left(\mathrm{dd}, 2 \mathrm{H},{ }^{3} J_{\mathrm{HH}}=6.4,{ }^{4} J_{\mathrm{HH}}=\right.$ $2.6 \mathrm{~Hz}, \mathrm{H}_{\text {bipy-5 }}$ ), $7.23\left(\mathrm{~s}, 2 \mathrm{H}, \mathrm{H}_{\text {imid }}\right), 6.96\left(\mathrm{~d}, 1 \mathrm{H},{ }^{2} J_{\mathrm{HH}}=13.1 \mathrm{~Hz}\right.$, lowfield $\mathrm{AB}$ part of $\left.\mathrm{NCH}_{2} \mathrm{~N}\right), 6.14\left(\mathrm{~d}, 1 \mathrm{H},{ }^{2} J_{\mathrm{HH}}=13.1 \mathrm{~Hz}\right.$, highfield $\mathrm{AB}$ part of $\mathrm{NCH}_{2} \mathrm{~N}$ ), 4.57 (septet, $2 \mathrm{H},{ }^{3} \mathrm{~J}_{\mathrm{HH}}=6.6 \mathrm{~Hz}$, $\left.\mathrm{NCH}(\mathrm{Me})_{2}\right), 4.05\left(\mathrm{~s}, 6 \mathrm{H}, \mathrm{C}_{\text {bipy-4 }}-\mathrm{OCH}_{3}\right), 2.69$ (s, 6H, C $\mathrm{imid}-\mathrm{CH}_{3}$ ), $1.61,1.40\left(\mathrm{~d}, 6 \mathrm{H},{ }^{3} J_{\mathrm{HH}}=6.6 \mathrm{~Hz}, \mathrm{NCH}\left(\mathrm{CH}_{3}\right)_{2}\right) .{ }^{13} \mathrm{C} \mathrm{NMR}(253 \mathrm{~K}$, $\left.126 \mathrm{MHz}, \mathrm{CD}_{3} \mathrm{CN}\right): \delta=167.8\left(\mathrm{C}_{\text {bipy-4}}\right), 157.5\left(\mathrm{C}_{\text {bipy-2}}\right), 153.0$ $\left(\mathrm{C}_{\text {bipy-6}}\right), 141.7\left(\mathrm{NC}_{\text {imid }} \mathrm{N}\right), 137.9\left(\mathrm{C}_{\text {imid }}-\mathrm{Rh},{ }^{1} J_{\mathrm{CRh}}=36.8 \mathrm{~Hz}\right)$, $123.7\left(\mathrm{C}_{\text {imid }}-\mathrm{H}\right), 113.0\left(\mathrm{C}_{\text {bipy-5 }}\right), 110.6\left(\mathrm{C}_{\text {bipy-3 }}\right), 61.1\left(\mathrm{NCH}_{2} \mathrm{~N}\right)$,

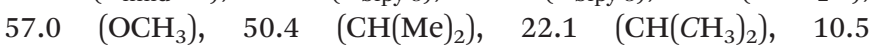


$\left(\mathrm{C}_{\text {imid }}-\mathrm{CH}_{3}\right)$. ESI-MS $(\mathrm{m} / \mathrm{z})$ : 833.0071, calcd for $[\mathrm{M}-\mathrm{I}]^{+}$ 833.0044. Anal. calcd for $\mathrm{C}_{27} \mathrm{H}_{36} \mathrm{I}_{3} \mathrm{~N}_{6} \mathrm{O}_{2} \mathrm{Rh}$ (960.23): C, 33.77; H, 3.78; N, 8.75. Found: C, 33.96; H, 3.61; N, 9.00.

[RhI 2 (C,C-dicarbene)(4,4'-dinitro-2,2'-dipyridyl)]I (2d). Following the general synthesis, $1(50 \mathrm{mg}, 0.034 \mathrm{mmol})$ and 4,4'dinitro-2,2'-bipyridine (17 $\mathrm{mg}, 0.069 \mathrm{mmol}$ ) afforded 2d (40 mg, 59\%) as a red coloured solid. ${ }^{1} \mathrm{H}$ NMR (253 K, $\left.500 \mathrm{MHz}, \mathrm{CD}_{3} \mathrm{CN}\right): \delta=9.70\left(\mathrm{~d}, 2 \mathrm{H},{ }^{3} \mathrm{~J}_{\mathrm{HH}}=6.0 \mathrm{~Hz}, \mathrm{H}_{\text {bipy-6}}\right), 9.40$ $\left(\mathrm{d}, 2 \mathrm{H},{ }^{3} J_{\mathrm{HH}}=2.0 \mathrm{~Hz} \mathrm{H}\right.$ bipy-3), $8.49\left(\mathrm{dd}, 2 \mathrm{H},{ }^{3} J_{\mathrm{HH}}=6.0 \mathrm{~Hz}\right.$, $\left.{ }^{4} J_{\mathrm{HH}}=2.0 \mathrm{~Hz}, \mathrm{H}_{\text {bipy-5}}\right), 7.32\left(\mathrm{~s}, 2 \mathrm{H}, \mathrm{H}_{\text {imid }}\right), 6.94\left(\mathrm{~d}, 1 \mathrm{H},{ }^{2} J_{\mathrm{HH}}=\right.$ 13.2 Hz, lowfield $\mathrm{AB}$ part of $\left.\mathrm{NCH}_{2} \mathrm{~N}\right), 6.16\left(\mathrm{~d}, 1 \mathrm{H},{ }^{2} J_{\mathrm{HH}}=13.2\right.$ $\mathrm{Hz}$, highfield $\mathrm{AB}$ part of $\mathrm{NCH}_{2} \mathrm{~N}$ ), 4.59 (septet, $2 \mathrm{H},{ }^{3} J_{\mathrm{HH}}=$ $\left.6.6 \mathrm{~Hz}, \mathrm{NCH}(\mathrm{Me})_{2}\right), 2.71$ (s, 6H, C imid $\left.-\mathrm{CH}_{3}\right), 1.64,1.41$ (d, 6H, $\left.{ }^{3} J_{\mathrm{HH}}=6.6 \mathrm{~Hz}, \mathrm{NCH}\left(\mathrm{CH}_{3}\right)_{2}\right) \cdot{ }^{13} \mathrm{C} \mathrm{NMR}(253 \mathrm{~K}, 126 \mathrm{MHz}$, $\left.\mathrm{CD}_{3} \mathrm{CN}\right): \delta=157.2\left(\mathrm{C}_{\text {bipy-2}}\right), 155.6\left(\mathrm{C}_{\text {bipy-4 }}\right), 155.2\left(\mathrm{C}_{\text {bipy-6}}\right), 142.4$ $\left(\mathrm{NC}_{\text {imid }} \mathrm{N}\right), 135.3\left(\mathrm{~d},{ }^{1} J_{\mathrm{CRh}}=37.3 \mathrm{~Hz}, \mathrm{C}_{\mathrm{imid}^{-}} \mathrm{Rh}\right), 123.9\left(\mathrm{C}_{\mathrm{imid}^{-}}\right.$ $\mathrm{H}), \quad 120.6\left(\mathrm{C}_{\text {bipy-5}}\right), \quad 118.6\left(\mathrm{C}_{\text {bipy-3 }}\right), \quad 61.4 \quad\left(\mathrm{NCH}_{2} \mathrm{~N}\right), \quad 50.7$ $\left(\mathrm{CH}(\mathrm{Me})_{2}\right), 22.2,22.1\left(\mathrm{CH}\left(\mathrm{CH}_{3}\right)_{2}\right), 10.6\left(\mathrm{C}_{\text {imid }}-\mathrm{CH}_{3}\right)$. ESI-MS $(\mathrm{m} / \mathrm{z}): 862.9495$, calcd for $\left[\mathrm{RhI}_{2}(\mathrm{C}, \mathrm{C}\right.$-dicarbene $)\left(4,4^{\prime}\right.$-dinitro-2,2'dipyridyl) $]^{+}$862.9535. Anal. calcd for $\mathrm{C}_{25} \mathrm{H}_{30} \mathrm{I}_{3} \mathrm{~N}_{8} \mathrm{O}_{4} \mathrm{Rh}$ (990.18): C, 30.32; H, 3.05; N, 11.32. Found: C, 30.04; H, 2.94; N, 11.07.

$\left[\mathrm{RhI}_{\mathbf{2}}(\mathrm{C}, \mathrm{C}-\right.$ dicarbene)(1,10-phen)]I (3). Following the general procedure, complex 1 (53 mg, $35.6 \mu \mathrm{mol})$ and 1,10-phenanthroline (14 mg, $78.4 \mu \mathrm{mol})$ afforded $3(62 \mathrm{mg}, 86 \%)$ as an orange coloured solid.

${ }^{1} \mathrm{H}$ NMR $\left(500 \mathrm{MHz}, \mathrm{CD}_{3} \mathrm{CN}\right): \delta=9.73\left(\mathrm{dd}, 2 \mathrm{H},{ }^{3} J_{\mathrm{HH}}=5.1 \mathrm{~Hz}\right.$, $\left.{ }^{4} J_{\mathrm{HH}}=1.4 \mathrm{~Hz}, \mathrm{H}_{\mathrm{phen}}\right), 8.70\left(\mathrm{dd}, 2 \mathrm{H},{ }^{3} J_{\mathrm{HH}}=8.2 \mathrm{~Hz},{ }^{4} J_{\mathrm{HH}}=1.4\right.$ $\left.\mathrm{Hz}, \mathrm{H}_{\text {phen }}\right), 8.21$ (s, 2H, $\left.\mathrm{H}_{\text {phen }}\right), 8.09\left(\mathrm{dd}, 2 \mathrm{H},{ }^{3} \mathrm{~J}_{\mathrm{HH}}=8.2 \mathrm{~Hz}\right.$, $\left.{ }^{4} J_{\mathrm{HH}}=5.1 \mathrm{~Hz}, \mathrm{H}_{\text {phen }}\right), 7.42\left(\mathrm{~s}, 2 \mathrm{H}, \mathrm{H}_{\text {imid }}\right), 7.11,6.24(\mathrm{br}, 1 \mathrm{H}$, $\mathrm{NCH}_{2} \mathrm{~N}$ ), 4.63 (septet, $\left.{ }^{3} \mathrm{~J}_{\mathrm{HH}}=6.7 \mathrm{~Hz}, \mathrm{CH}(\mathrm{Me})_{2}\right), 2.77(\mathrm{~s}, 6 \mathrm{H}$, $\left.\mathrm{C}_{\text {imid }}-\mathrm{CH}_{3}\right), 1.69,1.48$ (br, 6H, $\left.\mathrm{NCH}\left(\mathrm{CH}_{3}\right)_{2}\right) .{ }^{13} \mathrm{C}$ NMR $(253 \mathrm{~K}$, $\left.151 \mathrm{MHz}, \mathrm{CD}_{3} \mathrm{CN}\right): \delta=152.9\left(\mathrm{C}_{\text {phen }}-\mathrm{H}\right), 147.5\left(\mathrm{C}_{\text {phen }}\right), 142.3$ $\left(\mathrm{NC}_{\text {imid }} \mathrm{N}\right), 138.6\left(\mathrm{C}_{\text {phen }}-\mathrm{H}\right), 137.6\left(\mathrm{~d},{ }^{1} J_{\mathrm{CRh}}=37.2 \mathrm{~Hz}, \mathrm{C}_{\text {imid }^{-}}\right.$ $\mathrm{Rh}), 131.6\left(\mathrm{C}_{\text {phen }}\right), 128.4\left(\mathrm{C}_{\text {phen }}-\mathrm{H}\right), 126.4\left(\mathrm{C}_{\text {phen }}-\mathrm{H}\right), 124.4$ $\left(\mathrm{C}_{\text {imid }}-\mathrm{H}\right), 61.9\left(\mathrm{NCH}_{2} \mathrm{~N}\right), 51.2\left(\mathrm{NCH}(\mathrm{Me})_{2}\right), 22.6\left(\mathrm{NCH}\left(\mathrm{CH}_{3}\right)_{2}\right)$, $11.0\left(\mathrm{C}_{\text {imid }}-\mathrm{CH}_{3}\right)$. ESI-MS $(\mathrm{m} / \mathrm{z})$ : 796.9936, calcd for $[\mathrm{M}-\mathrm{I}]^{+}$ 796.9959. Anal. calcd for $\mathrm{C}_{27} \mathrm{H}_{32} \mathrm{I}_{3} \mathrm{~N}_{6} \mathrm{Rh}$ (924.20): C, 35.09; $\mathrm{H}$, 3.49; N, 9.09. Found: C, 34.60; H, 3.19; N, 8.79.

[RhI(C,C-dicarbene)(2,2'; $\mathbf{6}^{\prime}, 2^{\prime \prime}$-terpyridyl $\left.)\right](\mathrm{I})_{2} \quad$ (4). Following the general procedure, $1(150 \mathrm{mg}, 0.10 \mathrm{mmol})$ and $2,2^{\prime} ; 6^{\prime}, 2^{\prime \prime}-$ terpyridine $(60 \mathrm{mg}, 0.26 \mathrm{mmol}$ ) reacted to give 4 (175 $\mathrm{mg}$, $89 \%$ ) as a bright yellow coloured solid. Crystals of 4 suitable for X-ray diffraction studies were obtained by slow diffusion of $\mathrm{Et}_{2} \mathrm{O}$ into a $\mathrm{CH}_{2} \mathrm{Cl}_{2}$ solution of the complex.

${ }^{1} \mathrm{H}$ NMR $\left(400 \mathrm{MHz},\left(\mathrm{CD}_{3}\right)_{2} \mathrm{SO}\right): \delta=8.90\left(\mathrm{~d}, 2 \mathrm{H},{ }^{3} J_{\mathrm{HH}}=\right.$ $\left.8.1 \mathrm{~Hz}, \mathrm{H}_{\text {terpy }}\right), 8.78$ (d, 2H, $\left.{ }^{3} J_{\mathrm{HH}}=7.9 \mathrm{~Hz}, \mathrm{H}_{\text {terpy }}\right), 8.66(\mathrm{t}, 1 \mathrm{H}$, $\left.{ }^{3} J_{\mathrm{HH}}=8.1 \mathrm{~Hz}, \mathrm{H}_{\text {terpy }}\right), 8.43\left(\mathrm{~d}, 2 \mathrm{H},{ }^{3} \mathrm{~J}_{\mathrm{HH}}=5.7 \mathrm{~Hz}, \mathrm{H}_{\text {terpy }}\right), 8.28$ $\left(\mathrm{td}, 2 \mathrm{H},{ }^{3} J_{\mathrm{HH}}=7.9 \mathrm{~Hz},{ }^{4} J_{\mathrm{HH}}=1.2 \mathrm{~Hz}, \mathrm{H}_{\text {terpy }}\right), 7.68\left(\mathrm{~s}, 1 \mathrm{H}, \mathrm{H}_{\text {imid }}\right)$, 7.64-7.59 (m, 2H, H terpy), $6.02\left(\mathrm{~s}, 2 \mathrm{H}, \mathrm{NCH}_{2} \mathrm{~N}\right), 5.89(\mathrm{~s}, 1 \mathrm{H}$, $\mathrm{H}_{\text {imid }}$ ), 4.83 (septet, $1 \mathrm{H},{ }^{3} \mathrm{~J}_{\mathrm{HH}}=6.7 \mathrm{~Hz}, \mathrm{NCH}(\mathrm{Me})_{2}$ ), 4.34 (septet, $\left.1 \mathrm{H},{ }^{3} \mathrm{~J}_{\mathrm{HH}}=6.6 \mathrm{~Hz}, \mathrm{NCH}(\mathrm{Me})_{2}\right), 2.91\left(\mathrm{~s}, 3 \mathrm{H}, \mathrm{C}_{\text {imid }}-\mathrm{CH}_{3}\right), 2.61(\mathrm{~s}$, $\left.3 \mathrm{H}, \mathrm{C}_{\mathrm{imid}}-\mathrm{CH}_{3}\right), 1.60,1.01\left(\mathrm{~d}, 6 \mathrm{H},{ }^{3} J_{\mathrm{HH}}=6.6 \mathrm{~Hz}, \mathrm{NCH}\left(\mathrm{CH}_{3}\right)_{2}\right)$. ${ }^{13} \mathrm{C}$ NMR (101 MHz, $\left.\left(\mathrm{CD}_{3}\right)_{2} \mathrm{SO}\right): \delta=157.4$ (C $\left.\mathrm{C}_{\text {terpy }}\right), 154.5$ $\left(\mathrm{C}_{\text {terpy }}-\mathrm{H}\right), 152.7\left(\mathrm{C}_{\text {terpy }}\right), 143.33\left(\mathrm{NC}_{\text {imid }} \mathrm{N}\right), 143.27\left(\mathrm{NC}_{\text {imid }} \mathrm{N}\right)$, $141.2\left(\mathrm{C}-\mathrm{Rh},{ }^{1} J_{\mathrm{CRh}}=38.5 \mathrm{~Hz}\right), 140.3\left(\mathrm{C}_{\text {terpy }}-\mathrm{H}\right), 139.9\left(\mathrm{C}_{\text {terpy }}-\mathrm{H}\right)$, $133.2\left(\mathrm{C}-\mathrm{Rh},{ }^{1} J_{\mathrm{CRh}}=42.1 \mathrm{~Hz}\right), 128.1\left(\mathrm{C}_{\text {terpy }}-\mathrm{H}\right), 125.9\left(\mathrm{C}_{\text {terpy }}-\mathrm{H}\right)$,
$125.2\left(\mathrm{C}_{\text {imid }}-\mathrm{H}\right), \quad 124.7 \quad\left(\mathrm{C}_{\text {terpy }}-\mathrm{H}\right), \quad 114.2 \quad\left(\mathrm{C}_{\text {imid }}-\mathrm{H}\right), \quad 57.7$ $\left(\mathrm{NCH}_{2} \mathrm{~N}\right), 49.6,49.5\left(\mathrm{CH}(\mathrm{Me})_{2}\right), 22.3,21.5\left(\mathrm{CH}\left(\mathrm{CH}_{3}\right)_{2}\right), 10.5$, $10.2\left(\mathrm{C}_{\text {imid }}-\mathrm{CH}_{3}\right)$. ESI-MS $(\mathrm{m} / \mathrm{z}): 361.5526$, calcd for $[\mathrm{M}-2 \mathrm{I}]^{2+}$ 361.5527. Anal. calcd for $\mathrm{C}_{30} \mathrm{H}_{35} \mathrm{I}_{3} \mathrm{~N}_{7} \mathrm{Rh}(977.26) \cdot 1 \mathrm{CH}_{2} \mathrm{Cl}_{2}$ : C, 35.05; H, 3.51; N, 9.23. Found: C, 34.77; H, 3.45; N, 9.20.

\section{Typical procedure for catalytic transfer hydrogenation}

The precatalyst (4.5 $\mathrm{mol}, 0.15 \mathrm{~mol} \%)$ was weighed directly into the reaction vessel. To the vessel, $\mathrm{iPrOH}(15 \mathrm{~mL})$ and $\mathrm{KOH}$ (0.15 $\mathrm{mL}$ of $2 \mathrm{M}$ solution in $\mathrm{H}_{2} \mathrm{O}: 0.3 \mathrm{mmol}$ ) were added and the mixture was then heated to reflux temperature for $10 \mathrm{~min}$. in an oil bath $\left(110^{\circ} \mathrm{C}\right)$. Subsequently, the substrate $(3 \mathrm{mmol})$ was added directly and the reaction was sampled at set time intervals. The samples $(0.2 \mathrm{~mL})$ were quenched with cyclohexane $(2 \mathrm{~mL})$ and filtered through a short pad of Celite, which was then washed with $\mathrm{Et}_{2} \mathrm{O}(3 \times 2 \mathrm{~mL})$. The combined organic phases were evaporated to dryness $\left(40{ }^{\circ} \mathrm{C}, 100 \mathrm{mbar}\right)$ and then analysed by ${ }^{1} \mathrm{H}$ NMR spectroscopy. Selected runs with hexamethylbenzene as internal standard revealed that spectroscopic conversion of benzophenone and yield of diphenylmethanol were identical under these conditions.

\section{Crystal structure determinations}

Crystal data for $\mathbf{2 a}, \mathbf{2 b}$ and $\mathbf{4}$ were collected using a Rigaku (former Agilent Technologies) Oxford Diffraction SuperNova A diffractometer fitted with an Atlas detector and using monochromated $\mathrm{Mo}^{-\mathrm{K}_{\alpha}}$ radiation $(0.71073 \AA ̊)$ (2a) or $\mathrm{Cu}-\mathrm{K}_{\alpha}$ (1.54184 Å) (2b, 4). A complete dataset was collected, assuming that the Friedel pairs are not equivalent. The structures were solved by direct methods using SHELXS-97 and refined by fullmatrix least squares fitting on $F^{2}$ for all data using SHELXL-97. ${ }^{33}$ Hydrogen atoms were added at calculated positions and refined by using a riding model. Anisotropic thermal displacement parameters were used for all nonhydrogen atoms except for the disordered isopropyl group in $\mathbf{2 b}$. The solvents in 4 could not be modelled in terms of atomic size and the SQUEEZE option as incorporated in PLATON was used to compensate for the spread electron density. ${ }^{34}$ Crystallographic details are compiled in Tables S3 and S4. $\uparrow$ Crystallographic data (excluding structure factors) for all three complexes have been deposited with the Cambridge Crystallographic Data Centre as supplementary publication no. CCDC 1437163 (2a), 1437165 (2b), and 1437164 (4).

\section{Acknowledgements}

This work has been financially supported by a NUI Traveling Scheme (K.F.), by the European Research Council (CoG 615653) and Science Foundation Ireland (RFP/2010/CHS2844).

\section{References}

1 (a) A. P. Sadimenko, in Advances in Heterocyclic Chemistry, ed. A. R. Katritzky, Elsevier, Amsterdam, 2009, p. 45; 
(b) A. P. Smith and C. L. Fraser, in Comprehensive Coordination Chemistry II, ed. J. A. McCleverty and T. J. Meyer, Elsevier, Amsterdam, 2003, p. 1; (c) R. P. Thummel, in Comprehensive Coordination Chemistry II, ed. T. J. Meyer and J. A. McCleverty, Elsevier, Amsterdam, 2003, p. 41; (d) U. S. Schubert, A. Winter and G. R. Newkome, Terpyridine-Based Materials: for Catalytic, Optoelectronic and Life Science Applications, Wiley-VCH, Weinheim, 2011; (e) U. S. Schubert, H. Hofmeier and G. R. Newkome, Modern Terpyridine Chemistry, Wiley-VCH, Weinheim, 2006.

2 G. Chelucci and R. P. Thummel, Chem. Rev., 2002, 102, 3129.

3 (a) T. Ishiyama, J. Takagi, K. Ishida, N. Miyaura, N. R. Anastasi and J. F. Hartwig, J. Am. Chem. Soc., 2002, 124, 390; (b) I. A. I. Mkhalid, J. H. Barnard, T. B. Marder, J. M. Murphy and J. F. Hartwig, Chem. Rev., 2010, 110, 890; (c) T. Ishiyama, J. Takagi, J. F. Hartwig and N. Miyaura, Angew. Chem., Int. Ed., 2002, 41, 3056.

4 R. Kawahara, K.-I. Fujita and R. Yamaguchi, J. Am. Chem. Soc., 2012, 134, 3643.

5 (a) J. D. Blakemore, N. D. Schley, D. Balcells, J. F. Hull, G. W. Olack, C. D. Incarvito, O. Eisenstein, G. W. Brudvig and R. H. Crabtree, J. Am. Chem. Soc., 2010, 132, 16017; (b) J. DePasquale, I. Nieto, L. E. Reuther, C. J. Herbst-Gervasoni, J. J. Paul, V. Mochalin, M. Zeller, C. M. Thomas, A. W. Addison and E. T. Papish, Inorg. Chem., 2013, 52, 9175; (c) D. C. Marelius, S. Bhagan, D. J. Charboneau, K. M. Schroeder, J. M. Kamdar, A. R. McGettigan, B. J. Freeman, C. E. Moore, A. L. Rheingold, A. L. Cooksy, D. K. Smith, J. J. Paul, E. T. Papish and D. B. Grotjahn, Eur. J. Inorg. Chem., 2014, 676; (d) J. L. Cape, S. V. Lymar, T. Lightbody and J. K. Hurst, Inorg. Chem., 2009, 48, 4400; (e) J. K. Hurst, J. L. Cape, A. E. Clark, S. Das and C. Qin, Inorg. Chem., 2008, 47, 1753; (f) H. Yamada, W. F. Siems, T. Koike and J. K. Hurst, J. Am. Chem. Soc., 2004, 126, 9786; (g) R. A. Binstead, C. W. Chronister, J. Ni, C. M. Hartshorn and T. J. Meyer, J. Am. Chem. Soc., 2000, 122, 8464; (h) J. J. Concepcion, J. W. Jurss, M. K. Brennaman, P. G. Hoertz, A. O. T. Patrocinio, N. Y. Murakami Iha, J. L. Templeton and T. J. Meyer, Acc. Chem. Res., 2009, 42, 1954; (i) F. Liu, J. J. Concepcion, J. W. Jurss, T. Cardolaccia, J. L. Templeton and T. J. Meyer, Inorg. Chem., 2008, 47, 1727.

6 T. P. Brewster, W. C. Ou, J. C. Tran, K. I. Goldberg, S. K. Hanson, T. R. Cundari and D. M. Heinekey, ACS Catal., 2014, 4, 3034.

7 (a) W.-H. Wang, Y. Suna, Y. Himeda, J. T. Muckerman and E. Fujita, Dalton Trans., 2013, 42, 9628; (b) W. Li, J.-H. Xie, M.-L. Yuan and Q.-L. Zhou, Green Chem., 2014, 16, 4081; (c) P. Frediani, A. Salvini, M. Bessi, L. Rosi and C. Giannelli, Inorg. Chem. Commun., 2005, 8, 94; (d) P. Frediani, L. Rosi, L. Cetarini and M. Frediani, Inorg. Chim. Acta, 2006, 359, 2650; (e) O. Dayan, S. Dayan, İ. Kani and B. Çetinkaya, Appl. Organomet. Chem., 2012, 26, 663.

8 (a) F. E. Hahn and M. C. Jahnke, Angew. Chem., Int. Ed., 2008, 47, 3122; (b) A. J. Arduengo and G. Bertrand, Chem.
Rev., 2009, 109, 3209; (c) D. Bourissou, O. Guerret, F. P. Gabbaï and G. Bertrand, Chem. Rev., 2000, 100, 39; (d) N-Heterocyclic Carbenes in Transition Metal Catalysis, ed. F. Glorius, Topics in Organometallic Chemistry, Springer, Berlin, 2007; (e) M. N. Hopkinson, C. Richter, M. Schedler and F. Glorius, Nature, 2014, 510, 485; $(f)$ S. Díez-González, N. Marion and S. P. Nolan, Chem. Rev., 2009, 109, 3612; (g) C. M. Crudden and D. P. Allen, Coord. Chem. Rev., 2004, 248, 2247; (h) R. H. Crabtree, Coord. Chem. Rev., 2007, 251, 595; (i) N-Heterocyclic Carbenes: from Laboratory Curiosities to Efficient Synthetic Tools, ed. S. Díez-González, RSC Publishing, Cambridge, 2011; (j) N-Heterocyclic Carbenes in Transition Metal Catalysis and Organocatalysis, ed. C. S. J. Cazin, Springer, Berlin, 2011.

9 (a) K. Farrell and M. Albrecht, in The Privileged Pincer-Metal Platform: Coordination Chemistry \& Applications, Topics in Organometallic Chemistry, ed. G. van Koten and R. A. Gossage, Springer, Berlin, 2016, p. 45; (b) K. F. Donnelly, A. Petronilho and M. Albrecht, Chem. Commun., 2013, 49, 1145; (c) O. Schuster, L. Yang, H. G. Raubenheimer and M. Albrecht, Chem. Rev., 2009, 109, 3445; (d) A. T. Normand and K. J. Cavell, Eur. J. Inorg. Chem., 2008, 2008, 2781.

10 (a) V. Leigh, W. Ghattas, R. Lalrempuia, H. Müller-Bunz, M. T. Pryce and M. Albrecht, Inorg. Chem., 2013, 52, 5395; (b) M. Delgado-Rebollo, D. Canseco-Gonzalez, M. Hollering, H. Mueller-Bunz and M. Albrecht, Dalton Trans., 2014, 43, 4462; (c) W.-C. Chang, H.-S. Chen, T.-Y. Li, N.-M. Hsu, Y. S. Tingare, C.-Y. Li, Y.-C. Liu, C. Su and W.-R. Li, Angew. Chem., Int. Ed., 2010, 49, 8161; (d) O. Kaufhold, F. E. Hahn, T. Pape and A. Hepp, J. Organomet. Chem., 2008, 693, 3435.

11 (a) H.-J. Park, K. H. Kim, S. Y. Choi, H.-M. Kim, W. I. Lee, Y. K. Kang and Y. K. Chung, Inorg. Chem., 2010, 49, 7340; (b) D. G. Brown, N. Sanguantrakun, B. Schulze, U. S. Schubert and C. P. Berlinguette, J. Am. Chem. Soc., 2012, 134, 12354; (c) B. Schulze, D. Escudero, C. Friebe, R. Siebert, H. Goerls, U. Koehn, E. Altuntas, A. Baumgaertel, M. D. Hager, A. Winter, B. Dietzek, J. Popp, L. Gonzalez and U. S. Schubert, Chem. - Eur. J., 2011, 17, 5494; (d) S. Sinn, B. Schulze, C. Friebe, D. G. Brown, M. Jäger, E. Altuntaş, J. Kübel, O. Guntner, C. P. Berlinguette, B. Dietzek and U. S. Schubert, Inorg. Chem., 2014, 53, 2083; (e) D. G. Brown, P. A. Schauer, J. Borau-Garcia, B. R. Fancy and C. P. Berlinguette, J. Am. Chem. Soc., 2013, 135, 1692; (f) T.-A. Koizumi, T. Tomon and K. Tanaka, Organometallics, 2003, 22, 970; (g) L.-H. Chung, K.-S. Cho, J. England, S.-C. Chan, K. Wieghardt and C.-Y. Wong, Inorg. Chem., 2013, 52, 9885; (h) C.-Y. Wong, L.-M. Lai, P.-K. Pat and L.-H. Chung, Organometallics, 2010, 29, 2533.

12 (a) S. Gu and W. Chen, Organometallics, 2009, 28, 909; (b) S. Gu, B. Liu, J. Chen, H. Wu and W. Chen, Dalton Trans., 2012, 41, 962.

13 (a) E. Balaraman, E. Fogler and D. Milstein, Chem. Commun., 2012, 48, 1111; (b) E. Fogler, E. Balaraman, 
Y. Ben-David, G. Leitus, L. J. W. Shimon and D. Milstein, Organometallics, 2011, 30, 3826.

14 E. Balaraman, B. Gnanaprakasam, L. J. W. Shimon and D. Milstein, J. Am. Chem. Soc., 2010, 132, 16756.

15 (a) A. Juris, V. Balzani, F. Barigelletti, S. Campagna, P. Belser and A. von Zelewsky, Coord. Chem. Rev., 1988, 84, 85; (b) M. D. Purugganan, C. V. Kumar, N. J. Turro and J. K. Barton, Science, 1988, 241, 1645; (c) V. Balzani and A. Juris, Coord. Chem. Rev., 2001, 211, 97; (d) L. Spiccia, G. B. Deacon and C. M. Kepert, Coord. Chem. Rev., 2004, 248, 1329; (e) M. M. Richter, Chem. Rev., 2004, 104, 3003; (f) E. C. Constable, Chem. Soc. Rev., 2007, 36, 246; (g) M. D. Ward, Chem. Commun., 2009, 4487; (h) W. J. Youngblood, S.-H. A. Lee, K. Maeda and T. E. Mallouk, Acc. Chem. Res., 2009, 42, 1966; (i) A. J. McConnell, M. H. Lim, E. D. Olmon, H. Song, E. E. Dervan and J. K. Barton, Inorg. Chem., 2012, 51, 12511; $(j)$ L. Flamigni, J.-P. Collin and J.-P. Sauvage, Acc. Chem. Res., 2008, 41, 857; (k) M. K. Nazeeruddin, E. Baranoff and M. Grätzel, Solar Energy, 2011, 85, 1172; (l) M. K. Nazeeruddin and M. Grätzel, in Comprehensive Coordination Chemistry II, ed. T. J. Meyer and J. A. McCleverty, Elsevier, Amsterdam, 2003, p. 719.

16 (a) R. Visbal and M. C. Gimeno, Chem. Soc. Rev., 2014, 43, 3551; (b) L. Mercs and M. Albrecht, Chem. Soc. Rev., 2010, 39, 1903.

17 A. T. Normand and K. J. Cavell, Eur. J. Inorg. Chem., 2008, 2781.

18 For selected recent examples, see: (a) L.-H. Chung, Inorg. Chem., 2012, 51, 8693; (b) S. Conejero, P. Lara, M. Paneque, A. Petronilho, M. L. Poveda, O. Serrano, F. Vattier, E. Álvarez, C. Maya, V. Salazar and E. Carmona, Angew. Chem., Int. Ed., 2008, 47, 4380; (c) L.-H. Chung, K.-S. Chot, J. England, S.-C. Chan, K. Wieghardt and C.-Y. Wong, Inorg. Chem., 2013, 52, 9885; (d) M. Schmidtendorf, T. Pape and F. E. Hahn, Dalton Trans., 2013, 42, 16128; (e) R. Staehle, L. Tong, L. Wang, L. Duan, A. Fischer, M. S. G. Ahlquist, L. Sun and S. Rau, Inorg. Chem., 2014, 53, 1307; (f) T. Duchanois, T. Etienne, M. Beley, X. Assfeld, E. A. Perpete, A. Monari and P. C. Gros, Eur. J. Inorg. Chem., 2014, 3747; ( $g$ ) M. A. Larsen, C. V. Wilson and J. F. Hartwig, J. Am. Chem. Soc., 2015, 137, 8633; (h) S. A. Hauser, R. Tonner and A. B. Chaplin, Organometallics, 2015, 34, 4419.

19 (a) A. Krüger, A. Neels and M. Albrecht, Chem. Commun., 2010, 46, 315; (b) A. Krüger, L. J. L. Häller, H. Müller-Bunz, O. Serada, A. Neels, S. A. Macgregor and M. Albrecht, Dalton Trans., 2011, 40, 9911.

20 For reviews, see: (a) P. L. Arnold and J. Pearson, Coord. Chem. Rev., 2007, 251, 596; (b) O. Schuster, L. Yang, H. G. Raubenheimer and M. Albrecht, Chem. Rev., 2009, 109, 3445; (c) M. Melaimi, M. Soleilhavoup and G. Bertrand, Angew. Chem., Int. Ed., 2010, 49, 8810; (d) K. F. Donnelly, A. Petronilho and M. Albrecht, Chem. Commun., 2013, 49, 1145; (e) R. H. Crabtree, Coord. Chem.
Rev., 2013, 257, 755; $(f)$ M. Albrecht, Adv. Organomet. Chem., 2014, 62, 111.

21 For selected examples, see: (a) M. Heckenroth, E. Kluser, A. Neels and M. Albrecht, Angew. Chem., Int. Ed., 2007, 46, 6293; (b) L. Bernet, R. Lalrempuia, W. Ghattas, H. MüllerBunz, L. Vigara, A. Llobet and M. Albrecht, Chem. Commun., 2011, 47, 8058; (c) D. Canseco-Gonzalez, A. Petronilho, H. Müller-Bunz, K. Ohmatsu, T. Ooi and M. Albrecht, J. Am. Chem. Soc., 2013, 135, 13193; (d) J. A. Woods, R. Lalrempuia, A. Petronilho, N. D. McDaniel, H. Müller-Bunz, M. Albrecht and S. Bernhard, Energy Environ. Sci., 2014, 7, 2316; (e) B. Bagh, A. M. McKinty, A. J. Lough and D. W. Stephan, Dalton Trans., 2014, 43, 12842; $(f)$ M. Delgado-Rebollo, D. Canseco-Gonzalez, M. Hollering, H. Müller-Bunz and M. Albrecht, Dalton Trans., 2014, 43, 4462; $(g)$ P. K. Hota, G. Vijaykumar, A. Pariyar, S. C. Sau, T. K. Sen and S. K. Mandal, Adv. Synth. Catal., 2015, 357, 3162; (h) P. Daw, R. Petakamsetty, A. Sarbajna, S. Laha, R. Ramapanicker and J. K. Bera, J. Am. Chem. Soc., 2014, 136, 13987. See also: (i) E. Aldeco-Perez, A. J. Rosenthal, B. Donnadieu, P. Parameswaran, G. Frenking and G. Bertrand, Science, 2009, 326, 556.

22 L. Yang, A. Krüger, A. Neels and M. Albrecht, Organometallics, 2008, 27, 3161.

23 See for examples: (a) J. A. Mata, A. R. Chianese, J. R. Miecznikowski, M. Poyatos, E. Peris, J. W. Faller and R. H. Crabtree, Organometallics, 2004, 23, 1253; (b) F. E. Hahn, C. Holtgrewe, T. Pape, M. Martin, E. Sola and L. A. Oro, Organometallics, 2005, 24, 2203; (c) C. H. Leung, C. D. Incarvito and R. H. Crabtree, Organometallics, 2006, 25, 6099; (d) A. R. Chianese, B. M. Zeglis and R. H. Crabtree, Chem. Commun., 2004, 2176; (e) M. Viciano, M. Feliz, R. Corberan, J. A. Mata, E. Clot and E. Peris, Organometallics, 2007, 26, 5304.

24 (a) J. Hartwig, Organotransition Metal Chemistry, University Science Books, Mill Valley, CA, 2010; (b) R. H. Crabtree, The Organometallic Chemistry of the Transition Metals, WileyVCH, Weinheim, Germany, 6th edn, 2014.

25 (a) G. Zassinovich, G. Mestroni and S. Gladiali, Chem. Rev., 1992, 92, 1051; (b) D. Klomp, U. Hanefeld and J. A. Peters, in The Handbook of Homogeneous Hydrogenation, ed. J. G. de Vries and C. J. Elsevier, Wiley-VCH, Weinheim, Germany, 2007, p. 585; (c) S. Gladiali and E. Alberico, Chem. Soc. Rev., 2006, 35, 226; (d) D. Wang and D. Astruc, Chem. Rev., 2015, 115, 6621.

26 K. Farrell, H. Müller-Bunz and M. Albrecht, Organometallics, 2015, 34, 5723.

27 (a) M. Poyatos, W. McNamara, C. Incarvito, E. Clot, E. Peris and R. H. Crabtree, Organometallics, 2008, 27, 2128; (b) N. B. Jokić, M. Zhang-Presse, S. L. M. Goh, C. S. Straubinger, B. Bechlars, W. A. Herrmann and F. E. Kühn, J. Organomet. Chem., 2011, 696, 3900; (c) V. Gierz, A. Urbanaite, A. Seyboldt and D. Kunz, Organometallics, 2012, 31, 7532; (d) S. N. Sluijter and C. J. Elsevier, Organometallics, 2014, 33, 6389. 
28 (a) S. E. Clapham, A. Hadzovic and R. H. Morris, Coord. Chem. Rev., 2004, 248, 2201; (b) J. S. M. Samec, J.-E. Bäckvall, P. G. Andersson and P. Brandt, Chem. Soc. Rev., 2006, 35, 237.

29 (a) M. Poyatos, E. Mas-Marza, J. A. Mata, M. Sanau and E. Peris, Eur. J. Inorg. Chem., 2003, 1215; (b) A. Binobaid, M. Iglesias, D. Beetstra, A. Dervisi, I. Fallis and K. J. Cavell, Eur. J. Inorg. Chem., 2010, 5426.
30 R. P. Yu, J. M. Darmon, C. Milsmann, G. W. Margulieux, S. C. E. Stieber, S. DeBeer and P. J. Chirik, J. Am. Chem. Soc., 2013, 135, 13168.

31 O. Pamies and J.-E. Bäckvall, Chem. - Eur. J., 2001, 7, 5052.

32 S. Horn and M. Albrecht, Chem. Commun., 2011, 47, 8802.

33 G. M. Sheldrick, Acta Crystallogr., Sect. A: Fundam. Crystallogr., 2008, 64, 112.

34 A. L. Spek, J. Appl. Crystallogr., 2003, 36, 7. 